\title{
LEGAL PROTECTION OF LURIK ART CONSERVATION THROUGH INTELLECTUAL PROPERTY RIGHTS IN KLATEN REGENCY
}

\author{
Riska Andi Fitriono ${ }^{1}$; Sarwono ${ }^{2}$ \\ ${ }^{1}$ Doctoral Student in Law, Universitas Diponegoro; \\ ${ }^{2}$ The Faculty Of Fine Arts And Design Universitas Sebelas Maret \\ E-mail: riskaandi@staff.uns.ac.id; Sarwono59@staff.uns.ac.id
}

\begin{abstract}
This article aimed to analyze legal protection of Lurik Art Conservation Through Intellectual Property Rights in Klaten Regency. Klaten is the area that is most concerned with the survival of lurik weaving. There is someone mentioned that the Klaten Regency was the capital of lurik weaving. Because the weaving of Looms are not machines or Alat Tenun Bukan Mesin (hereinafter abbreviated to ATBM) is a mainstay of this city. There are countless villages that become centers of lurik craftsmen. This research is empirical or non-doctrinal research, which is a study that sees the law not only from the perspective of legislation, but also sees the law in its implementation. The results of the study show that the first legal protection in preserving the current lurik art in Klaten, namely the Klaten Regency Government, then stipulates the Regent's Regulation Number 53 of 2010 Article 23 Paragraph (9) on the Daily Batik and Traditional Weaving Lurik Service or ATBM Striated and the Klaten Regent's Decree Number : 065/1014/06 December 30, 2010 on Wearing Traditional Weaving, Motives, Colors and Free Models with Attributes. Furthermore, based on the Decree of the Regent of Klaten Number 050/84 of 2016 on Klaten Regency's Superior Products, batik striated is one of the superior products of Klaten Regency. With the issuance of these rules as an effort to protect and preserve lurik art in Klaten district and referring to Law Number 28 of 2014 on Copyright, it has regulated the forms of protection of lurik art in Klaten through Article 40 paragraph (1). The Second Protection of Intellectual Property Rights Against Lurik Art, namely Protection of lurik artworks, besides being accommodated in Law Number 28 of 2014 on Copyright (Copyright Law) and Trademark Law and other intellectual property right laws. Elucidation of Article 40 paragraph (1) letter $\mathrm{j}$ of the Copyright Law. The work is protected because it has artistic value, both in relation to the picture, style, and color composition. The Copyright Act also emphasizes that it is important to protect Copyright because every creator, in this case, the creator of the lurik motif has the right to moral rights and economic rights.
\end{abstract}

Keywords: Legal Protection; Striated Art. 


\section{INTRODUCTION}

Striated cloth art in Javanese society, is a source of inspiration that has never been explored and developed its values. The deeper the work is studied, the more amazing the contents are. Amazed at the aesthetics and meaning of the symbols implicitly or explicitly in the work. The form of culture in the form of lurik fabric craft is not only found in Java, but almost in Indonesia has a different name, but using the same media has been going on for a long time and is hereditary. Therefore, the art is also said to be a cultural art which is essentially cosmopolitan and universal.

Traditional lurik art has now experienced a shift in ownership. If originally only belonged to a community supporting a particular regional culture, now other regional communities also feel they own it. This relates to the understanding that Indonesian culture is the whole of regional cultures. Therefore, the traditional arts of certain regional cultures can get input taste or concept of other regional cultures. In fact, it is wide open for the traditional arts of the inclusion of ideas and tastes of other countries (Sedyawati, 1981: 39).

Today, Klaten is the area that is most concerned with the survival of lurik weaving. Nothing wrong if someone mentioned that the Klaten Regency was the capital of lurik weaving. Because the weaving of ATBM (Weaving Machine Not Machine) is a mainstay of this city. There are countless villages that become centers of lurik craftsmen. Even if we enter or pass through the city of Klaten, then at the entrance we will find a monument in the form of a statue of someone who is weaving with ATBM. The monument, which was built in 2012, stands on Jalan Raya YogyakartaSolo, or rather at the Tegalyoso intersection, Klaten. (Https://astinsoekanto.com/ ke-klaten-menguak-kisah-kain-tenun-lurik/)

The policy of the Klaten Regency government number 025/575/08 dated June 25,2008 , on the trial of the use of traditional weaving or batik service clothes in the region is one of the efforts of the Klaten Regency government to preserve the lurik cloth as a traditional cloth from the Klaten Regency whose existence began to sink. With this policy, it is expected to be able to increase the production of lurik weaving so that its existence as cultural heritage and traditions of the community and as a characteristic of lurik batik in Klaten Regency can remain and thrive. the melting of the Pedan striated cloth is due to large scale publications at the National scale to preserve batik cloth. Striated fabrics are woven fabrics with longitudinal decoration or strips. According to belief, each striated motif has its own function, the use of each motif is also different. The people until now still maintain the tradition to always be there and become a culture to develop the tradition of ATBM lurik weaving (non-machine looms).

Lurik Fabric in Klaten Regency is one of the cultural heritage that has survived until now. The existence of Lurik fabric is now starting to develop with the support 
of the Klaten Regency Government and also the Klaten community in general. Lurik fabric art industry and craftsmen began to rise with the existence of new hopes for the development of the business. Furthermore, all components of society together with the government are taking steps in a sustainable manner for protection including increasing legal awareness protecting the importance of the nation's culture, one of which is Batik and lurik, which has been recognized internationally. (Anastasia Riani Suprapti, Ratna Endah Santoso and Rahmawati, 2016: 398)

The Indonesian government certainly can more firmly secure the arts and cultural assets of the Indonesian Nation itself, because Indonesia is one of the countries that has ratified the formation of the World Trade Organization (WTO) through Law No. 7 of 1994. The consequence is that Indonesia must carry out the obligation to adjust its national legislation to the provisions of the WTO, including those relating to the Agreement on Trade-Related Aspects of Intellectual Property Rights (TRIPs-WTO). (Afrillyanna Purba, et al, 2005: 1)

The role of IPRS in economic development can not be doubted, because based on data, countries that have non-physical asset capital (intellectual capital) or capital based on science and technology contribute wealth that far exceeds the wealth based on physical or natural resources (SDA). For example, large countries like the United States in 1980 had income assets from knowledge-based intellectual capital at 36.5\% of GNP (Gross National Product), as well as Japan, Korea, and Singapore. They are more advanced than Indonesia which is rich in natural resources (Junus, 2003: 3).

This type of research is empirical or non-doctrinal research, that is research that looks at the law not only from the perspective of legislation but sees the law in its implementation, sees the law at work. (Soetandyo Wignyosoebroto, 2002: 194) Because this type of research is empirical research / sociological data needed is primary data and secondary data. Primary data obtained by in-depth interviews of the Klaten district lurik artists, both professional, academic and artists who know about the problem, experts who know the field of lurik craft, people involved in the world of lurik craft, related local government agencies, Process events in Javanese traditional ceremonies in Klaten. Secondary data was obtained through literature studies, namely Archives and documents and records obtained from various parties who can support this research, such as records of lurik, as well as regional regulations relating to IPRS protection in the lurik field. The research is located in the Klaten region.

\section{RESEARCH METHODS}

The type of this research uses normative legal research, a legal research that is conducted based on law and regulation and library material, which is known as secondary material. Related with this type of research, the approach used in this paper 
are legal approach and historical approach. these approach are done by reviewing the acts and regulations that related to the problem that is being discussed in this research and also this research conduct a review on Legal Protection Of Lurik Art Conservation Through Intellectual Property Rights In Klaten Regency.

\section{RESEARCH RESULTS AND DISCUSSION}

\section{A. Legal Protection in preserving the current Lurik Art in Klaten Regency}

Legal protection according to Andi Hamzah is protection covering the whole rules or norms and values regarding an aspect of community life that aims to achieve peace and prosperity of the community. Whereas legal protection according to the Indonesian dictionary is protection or regulation, the law is a rule that is officially considered binding and made by the government. So legal protection can be interpreted as a regulation made by the government to protect and regulate the association of people's lives in various fields. (Djubaidah and Muhamad Jumhana, 1997: 126)

As Batik Striated Crafts are selected to be the flagship product of Klaten Regency, the Klaten Regency Government then stipulates Regents Regulation Number 53 of 2010 Article 23 Paragraph (9) on Batik Daily and Traditional Weaving Services or Striated $A T B M$ and Klaten Regent Decree Number: 065/1014 / 06 December 30, 2010 on Wearing Traditional Weaving, Motives, Colors and Free Models with Attributes. (Risca Cynthiana Sugiyarwati, 2017: 73). Furthermore, based on the Decree of the Regent of Klaten Number 050/84 of 2016 on Klaten Regency's Superior Products, batik striated is one of the superior products of Klaten Regency. With the issuance of these rules as an effort to protect and preserve lurik art in Klaten district.

Law Number 28 of 2014 on Copyright has regulated forms of protection for Lurik art in Klaten Regency through Article 40 paragraph (1) letter J. Lurik is one of Indonesia's cultural heritage, making Lurik fabrics through conventional weaving processes is appropriate for protected and guarded. The most fundamental thing in the effort to preserve Lurik weaving is by continuing to develop Lurik weaving in Klaten Regency. The efforts of the juridical and non-juridical side have been made by the Klaten Regency Government to develop the lurik weaving industry. There are several factors that cause the protection of Copyright, which are:

1. From the side of the Klaten Government there are unclear regulations, no Inventory, no collective registration of Copyright, a minimal budget, and a lack of information about Copyright; 
2. From the side of Lurik craftsmen, there is still a lack of awareness and understanding of Copyright, as well as the length of the registration process and Copyright registration fees.

\section{B. Protection of Intellectual Property Rights Against Lurik Art in Klaten Regency}

The problem of lurik art as intellectual work. First, the strives belong to the individual as the creator. This happens because the striated cloth includes artistic creations created by the creator himself and meets the originality requirements. Second, regional property. This happens when the striated is a traditional work that has become public property because the age of protection has ended. Works like this are commonly referred to as the public domain. As public property, similar works cannot actually be claimed as regional property. The public domain must be interpreted on a national scale, or free from regional boundaries. Within the framework of this regulation, the Indonesian Copyright Act establishes restrictive rules. In essence, free public domain creation is used by citizens but not by foreigners. If there is a desire of foreigners to take advantage of Indonesian creation, he must request and obtain permission from the state (Supanto, 2009).

Definitively, in the creation of lurik klaten contains several elements, namely Creator, Creation, motifs, elements of art and originality. These elements can be explained through the 2014 Copyright Law Article 1 number (2), which states that: Pencipta adalah seorang atau beberapa orang yang secara sendiri-sendiri atau bersama-sama menghasilkan suatu ciptaan yang bersifat khas dan pribadi.

In relation to a work, read Article 1 number (3) of Law No. 28 of 2014 on Copyright as follows:

Creation is every work of copyright in the fields of science, art, and literature that results from inspiration, ability, thought, imagination, dexterity, skill, or expertise expressed in tangible form.

Rachmadi Usman (2001) states that in its pouring a work must have a distinctive form and show authenticity (original) as a personal creation.

Protection of lurik artwork has been accommodated in Law No. 28 of 2014 on Copyright (Copyright Law). Elucidation of Article 40 paragraph (1) letter j of the Copyright Law. The work is protected because it has artistic value, both in relation to the picture, style, and color composition. The Copyright Act also emphasizes that it is important to protect Copyright because every creator, in this case, the creator of the lurik motif has the right to moral rights and economic rights. So for other parties who want to exercise economic rights or moral rights are required to get permission from the creator. 
Therefore, in order to protect the moral rights and economic rights of the creators of lurik motives, legal remedies can be carried out, among others, through disability to the Directorate General of Intellectual Property, Ministry of Law and Human Rights, as regulated in Article 64 of the Copyright Law. The procedure for recording has also been regulated in Article 66 of the Copyright Law.

In addition, protection for creators of lurik art from counterfeiting batik products, which is often done by foreign producers, is becoming increasingly urgent. During this time, some lurik products made by Indonesian artisans are exported without any identity. So, arriving at the destination country, the product is then given another brand or label, and is recognized as a product of another country. Today, the Klaten Regency government needs to collaborate with relevant ministries to issue lurik certification, such as batik certification through the Ministry of Industry, which is named Batikmark.

So far, the Government Regulation that is expected to be the basis for controlling the use of foreign parties has not been resolved. In such a case, it is still very likely that foreigners will use traditional creations in the area for commercial exploitation without permission. For this reason, despite the lack of regulation, local communities need to be reminded of the need to safeguard the assets of the area from possible use by foreigners. To be sure, there is a kind of challenge currently facing. In addition to distortions of traditional values and even rituals, the most direct threats present in the form of exploitation and commercialization. Admittedly, there needs to be a balance and fairness in the concept of utilizing traditional works like that. There is a need for IPRS awareness for local communities of the wealth they have, and remind them to understand IPRS that is used to protect their wealth, in this case, traditional knowledge. In the logic of IPRS means explaining to them the conception of IPRS protection rules and norms, including the point of contact with traditional works. Only with sufficient understanding, their legal awareness will grow. That means the protection mechanism will work as expected. Thus, if legal awareness can be fostered, it would be unnecessary for wrong opinions and resistance to the exploitation of traditional works to occur. In the concept of law, all problems have solutions and solutions. this means, the activities of the lurik fabric crafters in Klaten who recently work to fulfill the "order" of Indonesians and foreigners, are not misunderstood as selling state assets or regional assets. According to observations, the order in question is based largely on technical specifications belonging to foreigners. However, it must be admitted, most of these mass products contain elements of local art or other traditional Indonesian elements. How should we deal with this problem certainly need to see it on a case by case basis? 
Industrial Design Concepts have unique features. As a creation of twodimensional or three-dimensional shapes and configurations or lines and colors, Industrial Design requires the ability to be used to make products or goods, including crafts, repeatedly. Because it involves handicraft works, it is proper if the maker is called a craftsman. Regulatory norms on industrial design have been standardized in Law No. 31 of 2000. The principles set out, among others, affirm the status of the person producing an Industrial Design with the title of Designer. In accordance with that understanding, there are several possibilities that are commonly found. First; the designer is just a "creator" of design. Second, the designer is the creator of the design as well as the craftsman who makes the works based on the designs he made. What is also possible is that crafters use designer designs because the latter person has no intention or ability to realize their own industrial designs.

Unlike Copyright, the principle of protection for Industrial Designs requires registration. Through a request for further registration, a formal and substantive examination will be carried out on all. predetermined requirements. Among them, novelty is required. In the phrase norm, novelty is a legal fact that proves that at the first time a request for registration is filed, no other party can argue the status of the design creation is not new or there has been prior disclosure. This legal norm is basically more of technical qualification. Which means, if technically no one can prove the existence of a similar design that was first registered or disclosed to the public, then the proposed design is considered as new. Other requirements refer to who first submitted the registration request. According to the law, that person is entitled to protection even though there are others who claim to make designs first. This principle is commonly called first to file system. The protection period is valid for 10 years from the date of receipt of the design registration request that has fulfilled the requirements.

Considering that the period of protection for design works is relatively short and there is no chance of extension, theoretically many industrial designs will become part and collection of regional assets with public domain status. With regard to public domain designs like that, the public has the right to use them freely. That is, there is no need to ask permission and do not pay royalties to anyone. The problem is, if such designs are made by local residents and the aesthetic elements really emphasize the nuances of local art or ethnic ornaments, then such work is commonly interpreted as regionally unique works. As a regional specialty, the local community will claim it as a regional asset.

In the national IPRS system, the conception of Geographical Indications has been adopted as part and brand of regulation. Since the Trademark Act 1992 until its change and replacement with Law Number 20 Year 2016, Geographical Indications have been accommodated. The format of the arrangement occupies 
a separate chapter combined with the original indication: Overall, the substance still requires further technical and operational arrangements. Among other things, arrangements for the procedure for registration, which until now have not been compiled.

According to Sardjono (2006: 18), it is assumed that the ownership of traditional knowledge belongs to the regions or the national dichotomy regarding its status. Protecting artisans in reality also have the dimension of providing protection to regional assets. However, thinking about the protection of regional assets must be distinguished from the perspective of IPRS protection. As long as the regional assets are individual works with IPRS, whoever owns them, no one is allowed to use them without the owner's permission. This premise is built and normative logic. After all, IPRS legal instruments will fully protect and protect them from unauthorized use practices. Unlike the case if what is done by the craftsmen just to do activities with the expertise, they have acquired from generation to generation. Such artisans do not create and do not produce new work that is qualified to qualify as a work that is entitled to copyright protection. Conversely, as mentioned earlier, if the commodities produced by the craftsmen have the characteristics and qualities associated with geographical factors, natural factors and human factors that exist in the area, most likely will apply for protection according to the Geographical Indication regime. However, protection according to the regime only applies through a sign that will only be registered if there is a party submitting a request for registration.

The connection with the conception of industrial design protection is basically not too relevant because this legal regime requires a renewal of the possibility of providing protection. Through the testing mechanism of novelty requirements and other technical requirements, design work will be considered for listing or rejected. If it meets the requirements and is registered, legal protection will apply to the Industrial Design.

Understanding the status of regional assets should be done by separating these assets from individual ownership. The status and existence of such individual assets are supported by IPRS laws and regulations. The rest are assets that do not have any exclusivity, no monopoly rights, and there is no prohibition on the use by anyone. Specifically in the Copyright Act, it is known that a ban on the use of public domain copyrighted works by foreign parties. If it has to be done, it is necessary to get permission first and the state.

So far, there have been almost no claims on regional assets protected by IPRS. This means that the region has never legally recognized as a sole proprietor with a monopoly right for assets containing IPRSs or has loaded IPRSs, except those with Geographical Indication dimensions. What has been decided as an 
asset belongs to the region actually has no justification. Such assets are part and national assets that are free to be used and used by anyone, including used by the craftsmen as long as they are citizens of the Republic of Indonesia. With this logic, claims that refer to regional scope need to be straightened out, especially in the era of regional autonomy. If autonomy is defined as the authority to manage regionally own households, this does not in any way provide a justification for regions to control and monopolize their own works. the status of the work of the area earlier.

if it is related to the characteristics of local people who are rights bearers from PTs who do not really care about the idea of legal protection for their rights to PT. Indonesian local people basically respect the values of togetherness and spiritual happiness in a shared life (harmony, harmony, teposeliro and other harmonious values), while the protection of IPRS is more individualistic-materialistic.

There are some homework that must be carried out on an ongoing basis so that the system of protection and utilization of Traditional Knowledge specifically lurik can be carried out in accordance with Indonesia's national interests and also provide benefits to the international community. The intended homework assignments are as follows:

a. IPRS must strengthen a sense of unity among fellow Indonesians in maintaining relations between members of the community in the country, the IPRS system should not be applied rigidly, for example, the application of a royalty value to a Traditional Knowledge and Folklore that is too high among fellow nations themselves;

b. The application of IPRS is more firmly applied in international trade relations. For this reason, it is necessary to evolve the regulation of protection and utilization of Traditional and Folklore Knowledge and its implementation in the field;

c. Intellectual Property Rights Protection Council needs to be established in the region, whose function is to provide recommendations on who has the right to channel the proceeds of royalties (such as collective management society) consisting of community leaders, masters and government officials (this institution may also be designated as a store of the Traditional Knowledge database and Folklore). The fund itself should ideally be managed by the district/city or provincial regional government which also functions as a decision-maker in its distribution.

d. Some of the royalty can also be used to finance regional development and supporting IPRS protection activities in the area. This is in accordance with the principle in Article 36 paragraph (3) of Law No. 39 of 1999 on Human Rights which stipulates that property rights have a social function. In addition, 
these funds can also be used for research on the origins of a Traditional and Folklore Knowledge which will be an "evidence" of ownership, a compilation of a database, and provide scholarships to those interested so that they can become human living treasures;

e. Special appreciation should be given to those individuals who are living human theories for preserving the existence of Traditional Knowledge and Folklore, in order to continue working to preserve and develop this kind of intellectual property;

f. It is necessary to determine who is the right holder or traditional and folklore knowledge;

g. It is necessary to determine whether the protection and use of traditional knowledge and folklore arrangements are based on the existing IPRS system or applying the sui generis system.

\section{CONCLUSION}

1. Legal Protection in preserving the current Striated Art in Klaten District, namely the Klaten Regency Government then stipulates Regents Regulation Number 53 Year 2010 Article 23 Paragraph (9) on Daily Batik and Traditional Weaving Services or Striated ATBM and Klaten Regent Decree Number: 065/1014 / 06 December 30, 2010 on Wearing Traditional Weaving, Motives, Colors and Free Models with Attributes. (Risca Cynthiana Sugiyarwati, 2017: 73). Furthermore, based on the Decree of the Regent of Klaten Number 050/84 of 2016 on Klaten Regency's Superior Products, batik striated is one of the superior products of Klaten Regency. With the issuance of these rules as an effort to protect and preserve lurik art in Klaten district and referring to Law Number 28 of 2014 on Copyright, it has regulated the forms of protection of lurik art in Klaten through Article 40 paragraph (1);

2. Protection of Intellectual Property Rights Against Striated Art, namely Protection of striated artworks besides being accommodated in Law Number 28 of 2014 on Copyright (Copyright Law) and Trademark Law and other IPR laws. Elucidation of Article 40 paragraph (1) letter $\mathrm{j}$ of the Copyright Law. The work is protected because it has artistic value, both in relation to the picture, style, and color composition. The Copyright Act also emphasizes that it is important to protect Copyright because every creator, in this case, the creator of the lurik motif has the right to moral rights and economic rights. So for other parties who want to exercise economic rights or moral rights are required to get permission from the creator. And also the Klaten Regency government needs to collaborate with the relevant ministries to issue lurik certification, such as batik certification through the Ministry of Industry, which is named Batikmark. 


\section{BIBLIOGRAPHY:}

\section{Books:}

Djubaidah and Muhamad Jumhana. (1997). Intellectual Property Rights (History, Theory and Practice in Indonesia). Bandung: Citra Adiyta Bhakti.

Hayman, D'Arcy. (1969). Introduction (The Arts and Man: A World View of the Role and Functions of the Arts in Society). France: Unesco.

Kesowo, Bambang. (1995). General Introduction on Intellectual Property Rights (IPR) in Indonesia. Yogyakarta: Faculty of Law UGM.

Purba, Afrillyanna, et al. (2005). TRIPS-WTO and Indonesian IPR Law, Jakarta: Rineka Cipta.

Sedyawati, Edi. (1981). Growth of Performing Arts. Jakarta: Sinar Harapan.

Supanto, Sarwono. (2009). Inventory and Identification of Tritic Arts and Jumps as Traditions in the Surakarta Region, Central Java (Study of the Development of Intellectual Property Rights in the Protection of "Traditional Knowledge"), Research, Surakarta: Sebelas Maret University

Wignyosoebroto, Soetandyo. (2002). Law Paradigm Method and the Dynamics of the Problem. Jakarta: Elsam and Huma.

\section{Journals:}

Cynthiana Sugiyarwati, Risca. (2017), Empowerment of Striated Batik Craftsmen Through One Village One Product (Ovop) Approach To Increase Village Community Revenues In Central Java Province. Scientific Journal of Regional Government Administration Volume IX.

Sardjono, Agus. (2006). Economic Potential of GRTKF: Opportunities and Barriers to Utilization: Intellectual Property Rights Viewpoint. IPR Media volume 1, Number 2

.Suprapti, Anastasia Riani, Ratna Endah Santoso dan Rahmawati. (2016). Innovation Design, Technology, And Marketing Website Through Batik And Lutik (Lurik Batik) Small Business Marketing Websites In Laweyan Surakarta District, Jurnal ekonomi dan bisnis Volume 19 No. 3, Desember 2016

\section{Websites:}

https://astinsoekanto.com/ke-klaten-mengak-kisah-kain-tenun-lurik

Junus, E. (2003). Legal Aspects in Disputes on Intellectual Property Rights Theory and Practice, Website: general.kompasiana.com/...hki, accessed on 28 July 2019 